\title{
POTENSI ANTIJAMUR TERHADAP ASPERGILLUS FLAVUS SENYAWA METABOLIT SEKUNDER ORGANISME LICHEN TELOSCHISTES FLAVICANS
}

\author{
Maulidiyah $^{1)}$, Asriani Hasan ${ }^{2)}$, Wa Ode Irna ${ }^{3)}$, Ishmah Farah Adiba Nurdinn), Akhmad \\ Darmawan $^{5)}$ \\ ${ }^{1)}$ Jurusan Kimia, Fakultas Matematika dan Ilmu Pengetahuan Alam, Universitas Halu \\ Oleo, Jl. HEA Mokodompit, Kendari 93232 - Sulawesi Tenggara, Indonesia \\ 2) Jurusan Kedokteran, Fakultas Kedokteran, Universitas Halu Oleo, Jl. HEA Mokodompit, \\ Kendari 93232 - Sulawesi Tenggara, Indonesia \\ ${ }^{3)}$ Pusat Penelitian Kimia, Lembaga Ilmu Pengetahuan Indonesia, Kawasan Puspitek, \\ Serpong 15314 - Indonesia
}

Email: ${ }^{1)}$ Maulidyah: maulid06@yahoo.com; Phone : +6281388327118

\begin{abstract}
ABSTRAK
Lichen adalah organisme simbiosis unik yang terbentuk dari hubungan mutualisme antara alga dan jamur. Lichen sangat potensial untuk dikembangkan sebagai bahan obat modern, terutama di Indonesia yang belum banyak meneliti tentang lumut. Penelitian ini bertujuan untuk mengisolasi dan uji aktivitas antijamur senyawa metabolit sekunder dari lichen Teloschistes flavicans. Penelitian ini dilakukan dengan mengekstraksi serbuk kering lichen dengan menggunakan pelarut aseton selama $3 \times 24$ jam. Ekstrak aseton diisolasi dengan kromatografi kolom $(K K)$ dan kromatografi lapis tipis (KLT) dengan fase diam silika gel G.60 yang dielusi dengan pelarut n-heksan dan etil asetat secara bertahap. Isolat kristalin dimurnikan dengan proses rekristalisasi. Senyawa murni ditentukan oleh strukturnya menggunakan UV-VIS, FTIR, LC-MS, dan IH-NMR. Senyawa yang diisolasi diperoleh jarum oranye "3-[1'- (2", 3"-dihydroxy-phenyl)-propyl]-7hydroxy-chroman-4-one" dengan rumus $\mathrm{C}_{18} \mathrm{H}_{18} \mathrm{O}_{5}$. Uji aktivitas antijamur terhadap Aspergillus flavus menggunakan metode difusi cakram menunjukkan bahwa zona hambat adalah $11 \mathrm{~mm}$ pada konsentrasi 1000 $m g / m L$.
\end{abstract}

Kata Kunci: Lichen, Teloschistes flavicans, antijamur, Aspergillus flavus 


\section{PENDAHULUAN}

Kecenderungan "back to nature" sangat dirasakan dalam dekade ini, dimana salah satu bidang yang tidak lepas dari kecenderungan ini adalah penggunaan obat untuk kesehatan. Indonesia sebagai salah satu negara megabiodiversity di dunia memiliki keanekaragaman hayati yang sangat melimpah dan memiliki potensi untuk digunakan sebagai bahan baku obat yang baru. Kesadaran masyarakat meningkat terhadap penggunaan obat bahan alam dikarenakan kurangnya efek samping yang ditimbulkan dibandingkan dengan obat-obatan sintetik $^{(i)}$. Seiring dengan hal tersebut, menyebabkan terjadinya peningkatan pencarian bahan baku obat dari bahan alam. Selain itu, peningkatan tersebut dipengaruhi oleh berbagai jenis penyakit dengan penyebab yang beragam. Dari sekian banyaknya bahan alam yang telah dijadikan bahan baku obat, salah satu yang perlu di kembangkan adalah lichen atau lumut kerak.

Lichen merupakan organisme bersimbiosis antara fungi (mikobiont) dari kelompok Ascomycetes dan Basidiomycetes, dengan alga (fikobiont) dari kelompok Cyanobacteria atau Chlorophyceae. Lichen dikenal sebagai organisme yang memiliki banyak potensi, khususnya dalam dunia pengobatan. Lichen telah digunakan dalam pengobatan tradisional sebagai obat luka, penyakit kulit, gangguan pernapasan, dan pencernaan ${ }^{(i i)}$.

Kandungan senyawa lichen terdiri dari banyak kelompok, seperti turunan asam amino, asam pulvinat, peptida, gula alkohol, terpenoid, steroid, karotenoid, asam alifatik, fenol monosiklik, depsida, depsidon dibenzofuran, antrakuinon, xanton dan turunan terpen lainnya ${ }^{(i i i, i v)}$. Kelompok senyawa tersebut yang memberikan aktivitas pengobatan yang jarang ditemukan pada tumbuhan maupun organisme lain. Senyawa kimia yang memiliki aktivitas biologi yang telah diisolasi dari lichen kurang lebih 350 dan 200 dari senyawa tersebut telah dikarekterisasi. Umumnya berbentuk kristal jarum yang memiliki bobot molekul rendah ${ }^{(\mathrm{v})}$.

Beberapa tahun terakhir, diketahui manfaat lichen diantaranya dapat digunakan sebagai $\operatorname{antioksidan}^{(\mathrm{vi})}$, antibakteri(vii), $\operatorname{antijamur}^{(\mathrm{viii}, \mathrm{ix})} \operatorname{antivirus}^{(\mathrm{x})}$, $\operatorname{antimalaria}^{(\mathrm{xi}, \mathrm{xii})}$, antiproliferatif ${ }^{(\mathrm{xiii})}$, aktivitas sitotoksik $^{(\mathrm{xiv})}$, dan anti $\mathrm{HIV}^{(\mathrm{xv})}$. Tingginya permasalahan keracunan bahan pangan yang diakibatkan oleh jamur Aspergillus flavus yang membahayakan kesehatan dan berakibat kronis bahkan mematikan. Dimana jamur A. flavus sangat mungkin untuk menyerang arteri paru-paru atau otak, dan dibuktikan dengan kasus ratusan orang meninggal di Kenya akibat infeksi jamur tersebut ${ }^{(x v i)}$. Senyawa aflatoksin 
mengakibatkan aflatoksikosis pada manusia atau ternak karena menghirup atau mengkonsumsi makanan atau pakan terkontaminasi aflatoksin dalam kadar yang tinggi.

Sehingga perlu dilakukan penelitian pencarian obat alami yang dapat menghambat pertumbuhan jamur yang tidak menimbulkan resistensi. Berdasarkan potensi lichen sebagai obat antijamur, maka perlu diteliti aktivitasnya terhadap jamur lain yang belum banyak dilaporkan yaitu A. flavus. Salah satu jenis lichen yang memiliki potensi untuk eksplorasi senyawa metabolit sekunder sebagai antijamur terhadap A. flavus adalah lichen Teloschistes flavicans, dimana kajian mengenai senyawa aktifnya juga belum banyak dilaporkan.

\section{METODE PENELITIAN}

Alat.

Alat-alat yang akan digunakan pada penelitian ini adalah rotary vacum evaporator, timbangan analitik, kolom, lampu UV ( $\lambda 254 \mathrm{~nm}$ dan $365 \mathrm{~nm})$, erlenmeyer, gelas ukur, gelas kimia, chamber, plat KLT, cawan porselen, mikropipet, pipet tetes, botol vial, penotol/pipa kapiler, statif \& klem, spatula, batang pengaduk, gunting, pinset, cutter, mistar, cawan petri, autoklaf, vortex, bunsen, tabung reaksi, spektrofotometer UV-VIS (Jasco, Jepang), LC-MS (Thermo Scientic), FTIR (shimadzu : irprestige 21), dan spektrometer NMR (JEOL JNM ECA 500).

\section{Bahan.}

Bahan-bahan yang digunakan adalah organisme lichen T. flavicans yang diambil di daerah pegunungan Desa Latimojong, Kecamatan Pasui, Kabupaten Enrekang, Provinsi Sulawesi Selatan, aseton (Merck, Germany), etil asetat (Merck, Germany), n-heksana (Merck, Germany), metanol (Merck, Germany), aqua bidestilata (IPHA, Indonesia), silika gel G.60 (0.063-0.200 mm), asam sulfat 10\% (Sigma-Aldrich), Potato Dextrose Agar (PDA) (Sigma-Aldrich), isolat jamur Aspergillus flavus, larutan $\mathrm{NaCl}$ fisiologis, ketokonazol, dan aluminium foil.

Metode.

Preparasi sampel.

Sampel lichen $T$. flavicans dibersihkan dari pengotornya dan dikeringkan pada suhu ruang. Sampel tersebut dipotong kecil dan dihaluskan menggunakan blender sampai 
diperoleh serbuk lichen kering. Selanjutnya, serbuk lichen ditimbang dan diperoleh sebanyak 560 gram.

\section{Isolasi dan Identifikasi Senyawa Kimia Lichen $T$. flavicans.}

Sebanyak 560 gram Serbuk lichen T. flavicans diekstraksi dengan cara maserasi menggunakan pelarut aseton selama $3 \times 24$ jam, dimana setiap 24 jam dilakukan penyaringan. Filtrat yang diperoleh dipekatkan menggunakan rotary vacum evaporator pada suhu 30$40^{\circ} \mathrm{C}$ hingga diperoleh ekstrak pekat. Ekstrak kemudian dipisahkan menggunakan kromatografi kolom gravitasi (KKG) dengan fasa diam silika gel G.60 dan eluen n-heksana: etil asetat secara gradien sampai diperoleh fraksi. Fraksi dianalisis menggunakan kromatografi lapis tipis (KLT) untuk melihat spot noda serta kemurnian senyawa. Senyawa murni diidentifikasi strukturnya menggunakan spektrometer UV-Vis, FTIR, LC-MS, dan ${ }^{1} \mathrm{H}-\mathrm{NMR}$.

\section{Uji Aktivitas Antijamur terhadap A. flavus.}

Uji aktivitas antijamur dilakukan menggunakan metode difusi cakram. Mula-mula alat dan bahan seperti cawan petri, tabung reaksi, media PDA disterilisasi menggunakan autoklaf pada suhu $121^{\circ} \mathrm{C}$ selama 30 menit. Jamur A. flavus diremajakan dengan menggunakan media Potato Dextrose Agar (PDA) selama 5-7 hari. Jamur yang telah diremajakan. Jamur diambil menggunakan kawat ose kemudian dimasukkan dalam tabung reaksi yang berisi larutan $\mathrm{NaCl}$ 0,9\%. Kemudian divortex hingga diperoleh kekeruhan sama dengan standar Mc farland yaitu dinyatakan sama dengan $10^{9} \mathrm{CFU} / \mathrm{mL}$.

Ekstrak dan senyawa isolat dibuat dalam beberapa konsentrasi, yaitu $1000 \mathrm{~g} / \mathrm{mL}, 750$ $\mathrm{g} / \mathrm{mL}, 500 \mathrm{~g} / \mathrm{mL}$, dan $100 \mathrm{~g} / \mathrm{mL}$. Kontrol positif digunakan ketokonazol dan kontrol negatif digunakan aseton. Suspensi jamur diambil sebanyak $1000 \mu \mathrm{L}$ kemudian dicampurkan dengan media PDA dan dituang dalam cawan petri dan dibiarkan sampai memadat. Selanjutnya disiapkan kertas cakram $(6 \mathrm{~mm})$ yang kemudian dicelupkan kedalam ekstrak dan senyawa isolat yang telah diencerkan. Selanjutnya, cakram tersebut diletakkan diatas permukaan media yang telah memadat diinkubasi selama 5-7 hari $\left(37^{\circ} \mathrm{C}\right)$ sampai terlihat zona bening disekitar cakram. Diameter zona bening yang terbentuk dihitung menggunakan jangka sorong. 


\section{HASIL DAN PEMBAHASAN}

\section{Hasil ekstraksi serbuk lichen.}

Hasil ekstraksi serbuk lichen diperoleh ekatrak pekat sebanyak 57,27 gram. Hasil isolasi menggunakan kromatografi kolom diperoleh 135 eluen yang kemudian dianalisis menggunakan KLT. Spot noda dengan nilai $R f$ yang sama digabung, sehingga diperoleh 12 fraksi. Setelah dilakukan pengamatan, fraksi F3 berbentuk kristal jarum berwarna jingga yang kemudian direkristalisasi hingga diperoleh senyawa murni. Analisis kemurnian senyawa dilakukan menggunakan KLT 2 dimensi. Hasil analisis dapat dilihat pada kromatogram Gambar 1.
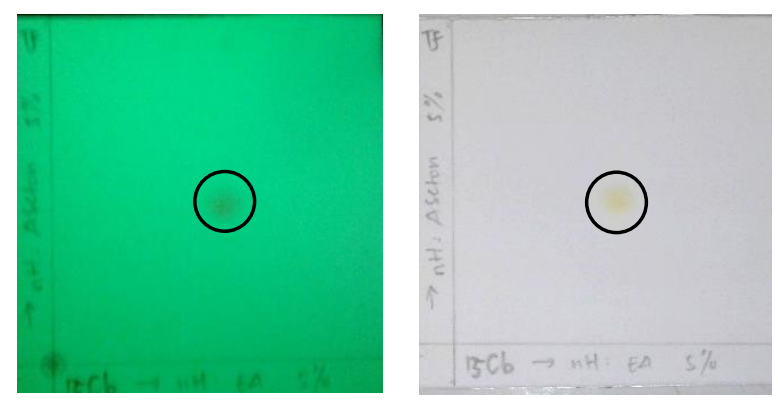

Gambar 1. Kromatogram KLT 2 dimensi dibawah UV 254 dan 365 nm

Spot noda yang terlihat pada kromatogram tampak tunggal yang menandakan bahwa senyawa isolat yang diperoleh telah murni. Isolat murni selanjutnya diidentifikasi strukturnya menggunakan spektrometer UV-Vis. Hasil yang diperoleh dapat dilihat pada Gambar 2.

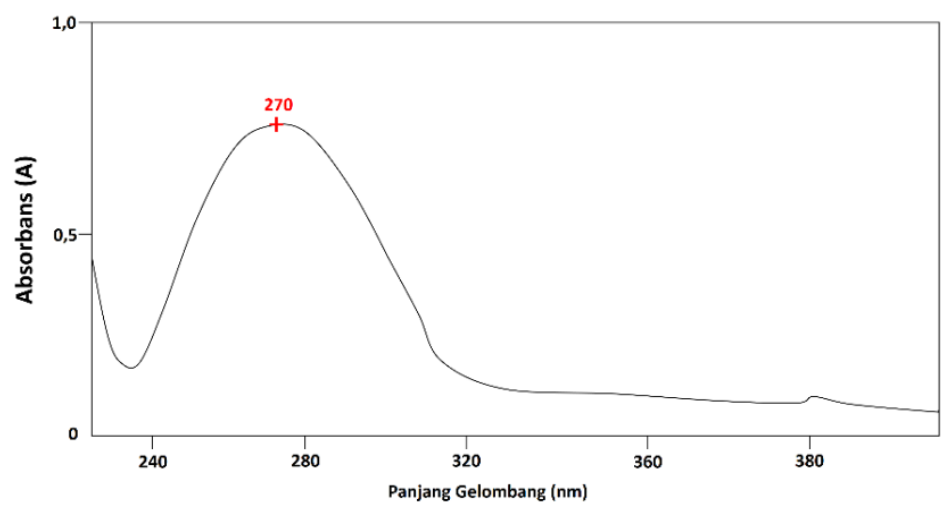

Gambar 2. Spektrum UV-Vis senyawa isolat

Berdasarkan hasil analisis spektrum UV-Vis senyawa isolat yang diukur pada panjang gelombang 200-400 nm, diketahui panjang gelombang maksimum yang diperoleh 
adalah $270 \mathrm{~nm}$. Serapan pada panjang gelombang tersebut menunjukkan adanya serapan karbonil yang umumnya terjadi pada 270-300 nm. Selanjutnya, berdasarkan hasil interpretasi data spektrum LC-MS (Gambar 3), diperoleh berat molekul senyawa isolat adalah $[\mathrm{M}+]=315,21$.

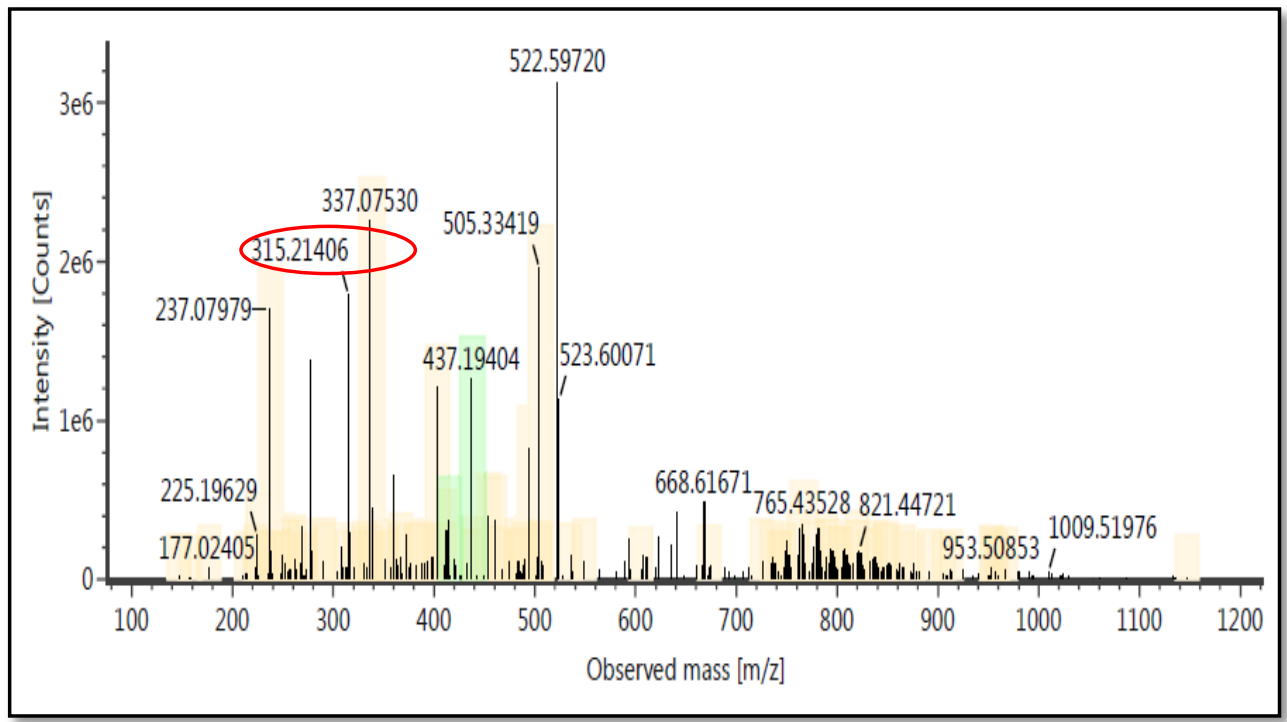

Gambar 3. Spektrum LC-MS senyawa isolat

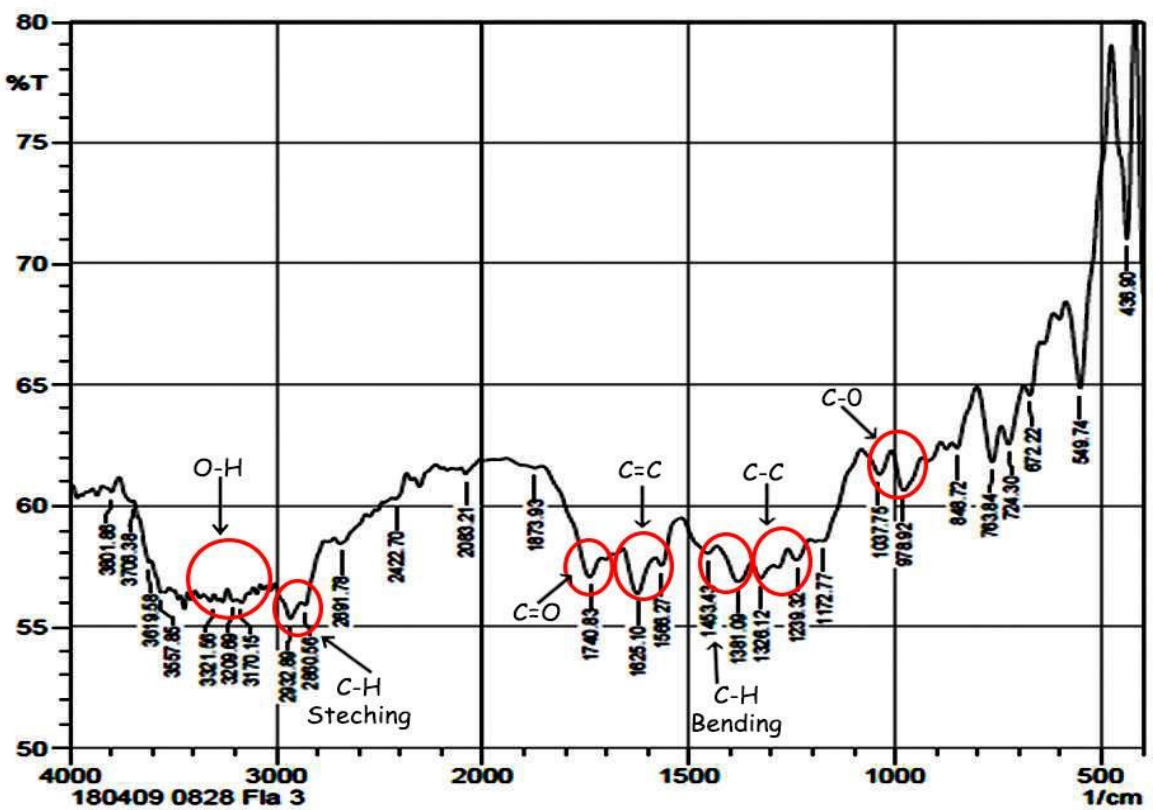

Gambar 4. Spektrum FTIR senyawa isolat

Gambar 4 menunjukkan ada beberapa karakteristik daerah serapan gugus fungsi yang muncul. Pita serapan yang muncul pada daerah $3321 \mathrm{~cm}^{-1}, 3209 \mathrm{~cm}^{-1}$, dan $3170 \mathrm{~cm}^{-1}$ mengindikasikan adanya gugus hidroksil (-OH), daerah serapan $2932 \mathrm{~cm}^{-1}$ dan $2860 \mathrm{~cm}^{-1}$ menunjukkan adanya vibrasi streching ikatan $\mathrm{C} s p^{3}-\mathrm{H}$ serta $\mathrm{C}-\mathrm{H}$ bending ditunjukkan pada 
daerah $1453 \mathrm{~cm}^{-1}$ dan $1381 \mathrm{~cm}^{-1}$. Serapan yang ditunjukkan pada daerah $1326 \mathrm{~cm}^{-1}$ dan 1239 $\mathrm{cm}^{-1}$ adalah adanya ikatan C-C. Keberadaan ikatan $\mathrm{C}=\mathrm{C}$ ditunjukkan pada daerah $1625 \mathrm{~cm}^{-}$ ${ }^{1}$ dan $1566 \mathrm{~cm}^{-1}$ serta uluran C-O pada daerah serapan $1037 \mathrm{~cm}^{-1}$ dan $978 \mathrm{~cm}^{-1}$. Berdasarkan data spektrum FTIR dapat disimpulkan bahwa senyawa isolat memiliki gugus fungsi hidroksil $(-\mathrm{OH})$, karbon alifatik $\left(\mathrm{CH}_{3}\right.$ dan $\left.\mathrm{CH}_{2}\right)$, karbonil $(\mathrm{C}=\mathrm{O})$, alkena $(\mathrm{C}=\mathrm{C})$, dan eter (C-O). Keberadaan gugus fungsi hasil analisis spektrum FTIR didukung oleh analisis spektroskopi ${ }^{1} \mathrm{H}-\mathrm{NMR}$ yang dapat dilihat dalam Gambar 5.

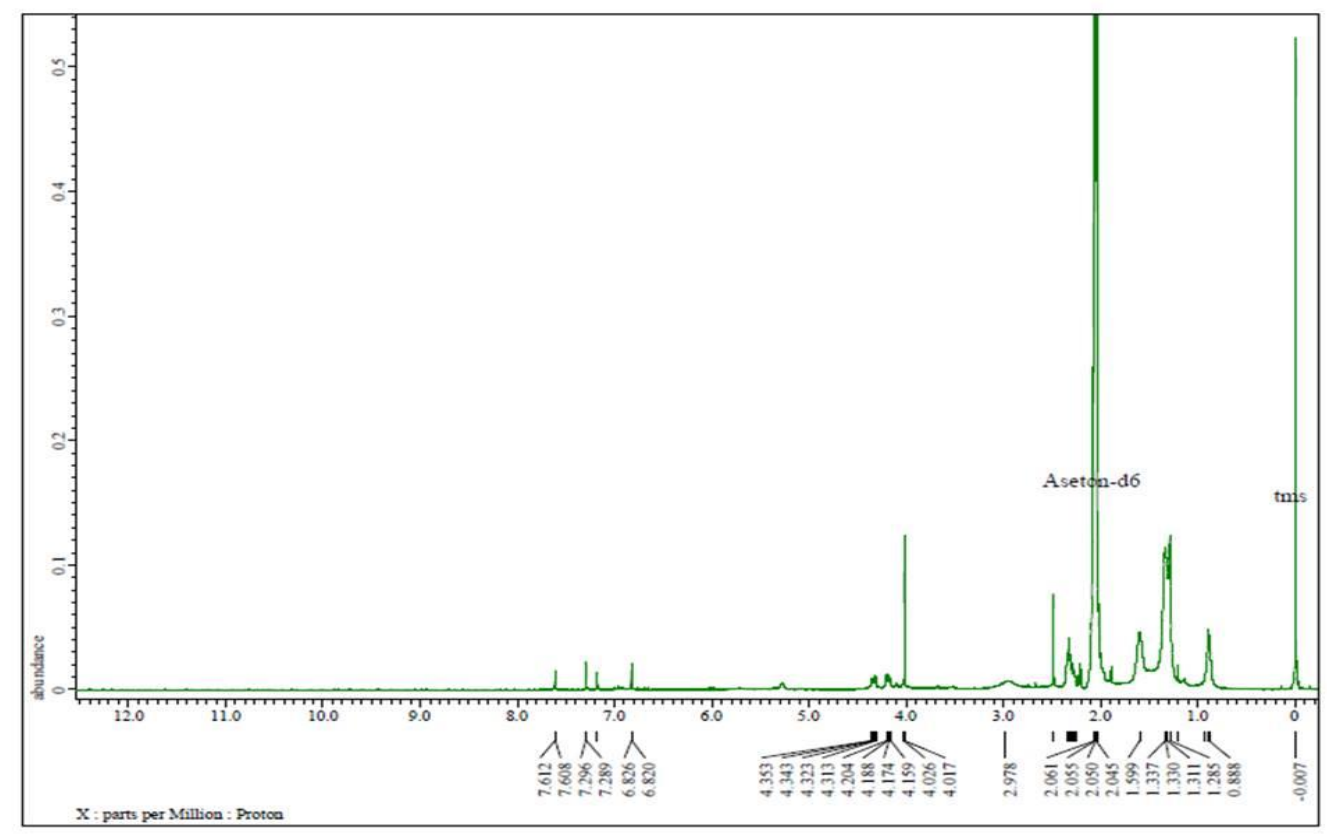

Gambar 5. Spektrum H-NMR senyawa isolat

Sinyal ${ }^{1} \mathrm{H}$ NMR isolat pada Gambar 5. memperlihatkan 13 jenis sinyal proton yang mewakili 18 proton. Terdapat 1 sinyal proton metil pada $\delta_{\mathrm{H}} 0,833$. Terdapat 4 jenis proton yang memiliki geseran kimia di atas 6 ppm yaitu 6,82; 7,182; 7,289 dan 7,612 ppm yang mengindikasikan bahwa proton tersebut memiliki kerapatan elektron yang rendah atau terikat pada gugus penarik elektron seperti alkena.

Tabel 1. Data ${ }^{1} \mathrm{H}-\mathrm{NMR}$ senyawa isolat

\begin{tabular}{cc}
\hline$\delta \mathrm{H}(\mathrm{ppm})$ & $\Sigma \mathrm{H}$, Mult., J $(\mathrm{Hz})$ \\
\hline 0,0883 & $1 \mathrm{H}, t, 3,5$ \\
1,33 & $1 \mathrm{H}, t, 3,5$ \\
1,599 & $1 \mathrm{H}, \mathrm{s}$ \\
\hline
\end{tabular}




\begin{tabular}{cc}
2,3 & $1 \mathrm{H}, \mathrm{q}$ \\
2,484 & $1 \mathrm{H}, \mathrm{s}$ \\
2,978 & $1 \mathrm{H}, \mathrm{s}$ \\
4,017 & $1 \mathrm{H}, \mathrm{s}$ \\
4,174 & $1 \mathrm{H}, d d, 7,5,8$ \\
4,343 & $2 \mathrm{H}, q, 5,5$ \\
6,82 & $1 \mathrm{H}, d, 3$ \\
7,182 & $1 \mathrm{H}, d, 1$ \\
7,289 & $1 \mathrm{H}, d, 3,5$ \\
7,612 & $1 \mathrm{H}, d, 2$ \\
\hline
\end{tabular}

Berdasarkan interpretasi data spektrum UV-Vis, LC-MS, FTIR, dan ${ }^{1} \mathrm{H}-\mathrm{NMR}$, senyawa isolat yang diperoleh mempunyai rumus molekul $\mathrm{C}_{18} \mathrm{H}_{18} \mathrm{O}_{5}$ dengan berat molekul $315,21 \mathrm{~g} / \mathrm{mol}$. Struktur senyawa yang diusulkan dapat dilihat pada Gambar 6.<smiles>CCC(c1cccc(O)c1O)C1COc2cc(O)ccc2C1=O</smiles>

3-[1'-(2",3"-dihydroxy-phenyl)-propyl]-7-hydroxy-chroman-4-one

Gambar 6. Struktur senyawa isolat

Hasil uji aktivitas antijamur ekstrak dan senyawa isolat lichen T. flavicans dapat dilihat pada Gambar 7.
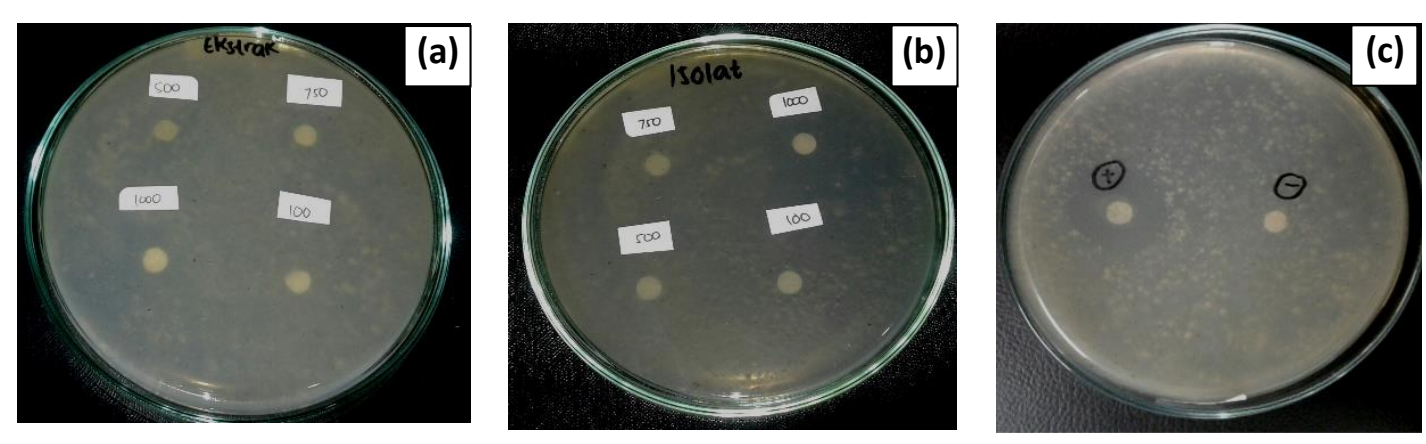
Gambar 7. Hasil Uji antijamur (a) ekstrak lichen T. flavicans (b) senyawa isolat (c)

Kontrol

\section{Hasil Uji Aktivitas Antijamur.}

Hasil pengukuran diameter zona bening pada uji aktivitas antijamur dapat dilihat pada Tabel 2 dan Tabel 3.

Tabel 2. Hasil pengukuran zona bening ekstrak lichen T. flavicans

\begin{tabular}{ccc}
\hline \multirow{2}{*}{ Konsentrasi $(\mathrm{mg} / \mathrm{mL})$} & \multicolumn{2}{c}{ Diameter Zona Hambat $(\mathrm{mm})$} \\
\cline { 2 - 3 } & Ekstrak & Isolat \\
\hline 1000 & 10 & 11 \\
750 & 7 & 8 \\
500 & 4 & 6 \\
100 & 0 & 0 \\
\hline
\end{tabular}

Tabel 3. Hasil pengukuran zona bening kontrol

\begin{tabular}{cc}
\hline Kontrol & Diamter Zona Hambat $(\mathrm{mm})$ \\
\hline Ketokonazol $(\mathrm{C}+)$ & 24 \\
Aseton $(\mathrm{C}-)$ & 0
\end{tabular}

Menurut Hutasoit et al. kategori hambatan terhadap pertumbuhan koloni jamur dapat dilihat pada Tabel 4 . 
Tabel 4. Kategori daya hambat terhadap pertumbuhan koloni jamur A. flavus $^{(\mathrm{xvii})}$

\begin{tabular}{cc}
\hline Zona Hambat $(\mathrm{mm})$ & Daya Hambat \\
\hline$\leq 5$ & Lemah \\
$6-10$ & Sedang \\
$11-20$ & Kuat \\
$>20$ & Sangat Kuat \\
\hline
\end{tabular}

Berdasarkan hasil pengukuran zona bening, ekstrak aseton lichen T. flavicans pada konsentrasi 1000 dan $750 \mathrm{mg} / \mathrm{mL}$ mempunyai aktivitas antijamur yang sedang dan pada 500 $\mathrm{mg} / \mathrm{mL}$ mempunyai aktivitas antijamur yang lemah. Senyawa isolat lichen $T$. flavicans pada konsentrasi $1000 \mathrm{mg} / \mathrm{mL}$ mempunyai aktivitas antijamur yang kuat, kemudian pada konsentrasi 750 dan $500 \mathrm{mg} / \mathrm{mL}$, aktivitasnya dalam menghambat jamur A. flavus adalah sedang. Sedangkan kontrol positif menghasilkan diameter zona bening $24 \mathrm{~mm}$ yang menandakan bahwa ketokonazol yang merupakan obat jamur komersil sangat kuat dalam menghambat pertumbuhan jamur A. flavus. Dengan demikian, ekstrak maupun senyawa isolat lichen $T$. flavicans mempunyai potensi dalam menghambat jamur A. flavus.

\section{KESIMPULAN}

Berdasarkan data spektrum dan elusidasi struktur senyawa isolat yang diperoleh dari lichen $T$. flavicans bahwa senyawa isolat memiliki rumus molekul $\mathrm{C}_{18} \mathrm{H}_{18} \mathrm{O}_{5}$ dengan berat molekul 315,21 g/mol. Senyawa tersebut diusulkan memiliki nama 3-[1'-(2",3"-dihydroxyphenyl)-propyl]-7hydroxy-chroman-4-one. Hasil uji antijamur ekstrak dan senyawa isolat, diperoleh data zona hambat tertinggi pada konsentrasi $1000 \mathrm{mg} / \mathrm{mL}$ yaitu $11 \mathrm{~mm}$. Hal tersebut menunjukkan bahwa senyawa metabolit sekunder yang telah diisolasi dari lichen $T$. flavicans dalam penelitian ini, memiliki aktivitas antijamur terhadap A. flavus.

Perlu dilakukan kajian bioaktivitas yang lebih mendalam untuk mengetahui konsentrasi bunuh minimum (KBM) pada ekstrak aseton lichen $T$. flavicans dan isolat dari lichen $T$. flavicans serta bioaktivitasnya terhadap jamur lainnya, sehingga memberi nilai tambah pada organisme tersebut. 


\section{UCAPAN TERIMA KASIH}

Ucapan terima kasih ditujukan kepada Kementrian Riset, Teknologi dan Pendidikan Tinggi (Kemristekdikti) atas pendanaan penelitian.

\section{DAFTAR PUSTAKA}

Maulidiyah, Sabarwati, S.H., Safutra, E., Nurdin, M. 2016. Atranorin secondary metabolite from lichen Usnea sp. and Its antibacterial activity. International Journal of Pharma and Bio Sciences. 7(3): 159-169.

Rankovic, B. 2015. Lichens Used in Traditional Medicine. Springer International Publishing. Switzerland.

Vivek, M.N., Manasa, Yashoda, K. Prashith, K.T.R, Raghavendra, H.L. 2014. Antifungal efficacy of three bioactive parmotrema species from western ghats of karnataka india. International Journal of Agriculture and Crop Sciences. 7(12): 968-973.

Babiah, P.S., Upreti, D.K., John, S.A. 2014. Fungicidal efficacy of a foliose lichen flavoparmelia caperata (L.) Hale against phytopthogenic fungi. International Journal of Current Research Bioscience and Plant Biology. 1(5):38-44.

Kosanic, M., Rankovic, B., Sukdolak, S. 2010. Antimicrobial activity of the lichen Lecanora frustulosa and Parmeliopsis hyperopta and their divaricatic acid and zeorin constituents. African Journal of Microbiology Research. 4(9): 888-890.

Pavithra, Vinayaka, K.S., Rakesh, K.N., Syed, J., Dileep, N., Prashith, K.T.R., Saba, S., Abhishiktha, S.N. 2013. Antimicrobial and antioxidant activities of a macrolichen Usnea pictoides G. Awasthi (Parmeliaceae). Journal of Applied Pharmaceutical Science. 3(8): 154-160.

Maulidiyah, Imran, Watu, M., Nurdin, M. 2016. Secondary Metabolites Identification from Lichen Usnea Longissima Ach: Bioactivity Test of Antibacteria. International Journal of Applied Chemistry. 12(3): 347-357.

Sasidharan, N.K., Sreerag, R.S., Rajesh, L., Jubi, J., Dileep, K.B.N., Saraswathy, A., Bala, N. 2014. Protolichesterinic acid: a prominent broad spectrum antimicrobial compound from the lichen usnea albopunctata. International Journal of Antibiotics. 6(1): 1-6.

Guo, S., Wen-Xia, L., Liu-Fu, H., Jia-Zhang, C. 2017. Antifungal activity of lichen extracts and usnic acid for controlling the saprolegniasis. International Journal of Environmental and Agriculture Research. 3(5): 43-44. 
Fazio, A.T., Adler, M.T., Bertoni, M.D., Sepulveda, C.S., Damonte, E.B., Maier, M.S. 2007. Lichen secondary metabolites from the cultured lichen mycobionts of teloschistes chryshophtalmus and ramalina celastri and their antiviral activities. Z. Naturforsch. 62(7): 543-549.

Maulidiyah, Thamrin, A., Hadija, S., Nurdin, M. 2015. Isolasi dan identifikasi senyawa (-)asam usnat dari lichen usnea sp. serta aktivitas sitotoksiknya terhadap sel murine leukemia P388. Jurnal Ilmu Kefarmasian Indonesia. 13(1): 40-44.

Dini, I., Maryono, Akmal, Sitti, H. 2017. Phytochemical analysis and antimalarial activity of usnea sp. from south sulawesi against P. falciparum. International Journal of Current Microbiology and Applied Science. 6(9): 1653-1660.

Mitrovic, T., Stamenkovic, S., Cvetkovic, V. 2011. Antioxidant, antimicrobial and antiproliferative activities of five lichen species. International Journal Molecular Science. 12: 5428-5448.

Maulidiyah, Cahyana, A.H., Suwarso, W.P., Nurdin, M. 2015. Isolation and structure elucidation of eumitrin A1 from lichen usnea blepharea Motyka and Its cytotoxic activity. International Journal Pharmaceutical Technology Research. 8(4): 782-789.

Emadi, S.N., Bhatt, S.M., M'Imunya, J.M., Suleh, A.J., Raeeskarami, S.R., Rezai, M.S., Navaeifar, M.R. 2014. Cutaneous manifestation in children with HIV/AIDS. Journal of Pediatric Review. 2(1): 17-28.

Lewis, Onsongo, L.M., Njapau, H., Schurz-rogers, H., Luber, G., Kieszak, S., Nyamongo, J., Backer, L., Dahiye, A.M., Misore, A., Decock, K., Rubin, C. 2005. Aflatoxin contamination of commercial maize products during an outbreak of acute aflatoxicosis in eastern and central Kenya. Environmental Health Perspective. 113(12): 1763-1766.

Hutasoit, S., Suada, I.K, Susrama, I.G. 2013. Uji aktivitas antijamur ekstrak beberapa jenis biota laut terhadap Aspergillus flavus LINK dan Penicillium sp. LINK. E-Jurnal Agroekoteknologi Tropika. 2(1): 27-38. 